MOSQUITO TRAP UNTUK MENGURANGI GANGGUAN NYAMUK DI LABORATORIUM KEBUN BIOLOGI FMIPA UNY

\title{
MOSQUITO TRAP IN THE LABORATORY OF FMIPA UNY'S BIOLOGICAL GARDEN TO REDUCE MOSQUITO DISORDERS
}

\author{
Dian Saputra, Fauziah Rahmawati, Devia Khoirun Nisa, Astried Hanggana Putri, \\ dan Rio Christy Handziko, S.Pd.Si., M.Pd.
}

Jurusan Pendidikan Biologi Universitas Negeri Yogyakarta, email:dian.ckj@gmail.com

\begin{abstract}
Abstrak
Nyamuk merupakan hewan yang sangat sering dijumpai di kehidupan sehari-hari. Mulai dari di lingkungan rumah, sampai di lingkungan sekolah. Nyamuk juga merupakan hewan yang dapat membawa berbagai macam penyakit. Laboratorium Kebun Biologi FMIPA UNY banyak ditumbuhi pohon-pohon dan terdapat genangan air dari beberapa kolam yang sengaja dibuat. Hal itulah yang menjadikan nyamuk menyukai lingkungan yang termasuk ke dalam habitatnya. Di Laboratorium Kebun Biologi UNY yang merupakan salah satu lokasi belajar mahasiswa banyak ditemukan nyamuk yang beterbangan dan terkadang mengganggu aktivitas belajar karena dapat menusuk dan menimbulkan rasa gatal. Gangguan tersebut dikhawatirkan akan menimbulkan penyakit dari nyamuk pada mahasiswa yang beraktivitas di kebun biologi. Sehingga dibuatlah alat perangkap nyamuk yang dimodifikasi dan disesuaikan dengan kebutuhan dan lokasi sasaran. Alat yang dibuat merupakan perangkap nyamuk sederhana yang memanfaatkan genangan air dari kolam ikan dan jaring dari kain jala atau paranet. Tempat sasaran adalah Laboratorium Kebun Biologi FMIPA UNY terutama wilayah kolam. Sedangkan target sasaran adalah jentik-jentik atau benih nyamuk yang ditinggalkan oleh induknya. Diharapkan nyamuk-nyamuk akan hinggap di atas paranet untuk bertelur, kemudian telur akan jatuh ke bawah dan akan dimakan oleh ikan. Hal ini selain untuk mengurangi pertumbuhan nyamuk, juga dapat digunakan untuk alternatif makanan untuk ikan, yang dapat mengurangi pengeluaran untuk membeli pakan ikan.
\end{abstract}

Kata kunci: lingkungan, perangkap, nyamuk.

\begin{abstract}
Mosquitoes are animals that are very often found in everyday life. Starting from the home environment, to the school environment. Mosquitoes are also animals that can carry various diseases. The FMIPA UNY Biology Garden Laboratory is overgrown with trees and there is a pool of water from several ponds that are deliberately made. That is what makes mosquitoes like the environment that is included in their habitat. At the UNY Biology Garden Laboratory, which is one of the student learning locations, mosquitoes are found flying and sometimes disrupting learning activities because they can stab and cause itching. The disturbance is feared to cause mosquito-borne diseases in students who are active in biology gardens. So that mosquito traps are made that are modified and adapted to the needs and location of the target. The tool made is a simple mosquito trap that utilizes a pool of water from a fish pond and a net from mesh or paranet cloth. The target place is the FMIPA UNY Biology Garden Laboratory, especially the pool area. While the target is the larvae or seeds of mosquitoes left by the mother. It is expected that the mosquitoes will perch on the paranet to lay eggs, then the eggs will fall down and will be eaten by fish. This is in addition to reducing the growth of mosquitoes, it can also be used for alternative food for fish, which can reduce spending to buy fish feed.
\end{abstract}

Key words: environment, mosquitos, trap. 


\section{PENDAHULUAN}

Kenyamanan belajar merupakan suatu hal yang sangat diperlukan dalam proses pembelajaran, agar proses belajar yang dilakukan dapat mendapatkan hasil yang maksimal. Salah satu faktor penting yang mendukung kenyamanan dalam belajar adalah dengan menjaga lingkungan sekitar tempat belajar kita dengan bersih, apalagi ketika dihadapkan dengan pembelajaran di luar ruang kelas misalnya di laboratorium kebun biologi.

Lingkungan adalah seluruh faktor luar yang memengaruhi suatu organisme; faktorfaktor ini dapat berupa organisme hidup (biotik faktor) atau variabel-variabel yang tidak hidup (abiotik faktor). Dari hal inilah kemudian terdapat dua komponen utama lingkungan, yaitu: a) Biotik: Makhluk (organisme) hidup; dan b) Abiotik: Energi, bahan kimia, dan lain-lain.

Permasalahan yang muncul ketika sedang melakukan pembelajaran di Laboratorium Kebun Biologi FMIPA UNY adanya gigitan nyamuk yang membuat pembelajaran terganggu. Di daerah tropis seperti Indonesia, nyamuk merupakan serangga yang sering mengganggu kehidupan manusia(Gama, Yanuwiadi, \& Kurniati, 2010). Nyamuk dapat mengganggu manusia dan binatang melalui gigitannya serta berperan sebagai vektor penyakit pada manusia dan binatang yang penyebabnya terdiri atas berbagai macam parasit dan virus(Nadifah, Farida Muhajir, Arisandi, \& D. Owa Lobo, 2017)

Di daerah tropis seperti Indonesia, nyamuk merupakan serangga yang sering mengganggu kehidupan manusia. Selain itu nyamuk juga dapat menyebarkan penyakit Malaria, Demam Berdarah Dengue (DBD) dan Filariasis(Gama et al., 2010).

Indonesia adalah salah satu negara tropis yang paling besar di dunia. Iklim tropis menyebabkan adanya berbagai penyakit tropis yang disebabkan oleh nyamuk, seperti malaria, demam berdarah, filaria, kaki gajah, dan chikungunya sering berjangkit di masyarakat, bahkan menimbulkan epidemi yang berlangsung dalam spektrum yang luas dan cepat. Penyebab utama munculnya epidemi berbagai penyakit tropis tersebut adalah perkembangbiakan dan penyebaran nyamuk sebagai vektor penyakit yang tidak terkendali(Kadarohman, 2010).

Jumlah nyamuk di lingkungan masyarakat cukup melimpah, hal ini dipengaruhi oleh bentuk anatomi nyamuk yang relatif kecil dan mampu beradaptasi dengan berbagai kondisi lingkungan (Khoiriyah, 2016). Nyamuk betina menggigit manusia dan nyamuk jantan hanya tertarik pada cairan mengandung gula seperti pada bunga. Biasanya nyamuk menggigit pada siang hari saja. Malam harinya lebih suka bersembunyi di sela-sela pakaian yang tergantung atau gorden, terutama di ruang gelap atau lembab. Mereka mempunyai kebiasaan menggigit berulang kali. Nyamuk ini memang tidak suka air kotor seperti air got atau lumpur kotor. Bertelur serta pembiakannya di atas permukaan air pada dinding yang bersifat vertikal dan terlindung pengaruh matahari langsung (Djakaria, 2000).

Tercatat lebih dari tiga ribu spesies nyamuk yang beterbangan di muka bumi ini, baik di tempat yang beriklim panas maupun beriklim dingin. Meskipun mampu hidup di kutub, sebagian besar nyamuk lebih suka hidup di daerah yang beriklim tropis dengan kelembaban tinggi seperti di Indonesia (Sunaryo, 2001).

Nyamuk betina dapat hidup kurang dari 3 minggu, nyamuk jantan biasanya hanya hidup sekitar satu minggu. Umumnya telur menetas di tempat yang berisi air. Telurtelur menetas menjadi larva. Larva bernapas dengan tabung di ujung ekornya, memakan organisme mikroskopis seperti bakteri. Dengan demikian sebagian besar larva nyamuk membutuhkan air yang mengandung bahan organik. Dalam waktu kurang dari satu minggu, larva dapat tumbuh dan berkembang menjadi pupa berbentuk koma

Ciri-ciri nyamuk. 
a) Badan kecil, warna hitam dengan bintikbintik putih.

b) Pertumbuhan telur sampai dewasa \pm 10 hari.

c) Menggigit/menghisap darah pada siang hari.

d) Senang hinggap pada pakaian yang bergantungan dalam kamar.

e) Bersarang dan bertelur di genangan air jernih di dalam dan di sekitar rumah yang agak gelap dan lembab

f) Hidup dalam rumah dan di sekitar rumah.

g) Di dalam rumah : bak mandi, tempayan, vas bunga, tempat minum burung. $h$. Di luar rumah : drum, tangki penampungan air, kaleng bekas, ban bekas, botol pecah, potongan bambu, tempurung kelapa, dan lain-lain (Chemika, 2004).

Biasanya nyamuk menggigit pada siang hari saja. Malam harinya lebih suka bersembunyi di sela-sela pakaian yang tergantung atau gorden, terutama di ruang gelap atau lembab. Mereka mempunyai kebiasaan menggigit berulang kali. Nyamuk ini memang tidak suka air kotor seperti air got atau lumpur kotor. Bertelur serta pembiakannya di atas permukaan air pada dinding yang bersifat vertikal dan terlindung pengaruh matahari langsung(Srisasi, 2000)

Keberadaan nyamuk di Laboratorium Kebun Biologi UNY ini memiliki efek positif yaitu bisa digunakan sebagai objek penelitian, maupun sebagai penyeimbang ekosistem yang ada di kebun biologi. Disisi lain, nyamuk juga memiliki efek negatif bagi manusia, khususnya bagi mahasiswa yang sedang melakukan pembelajaran di Laboratorium Kebun Biologi UNY, dari 5 mahasiswa yang kami wawancarai, tiga diantaranya merasa terganggu dengan gigitan nyamuk tersebut, efek samping setelah digigit nyamuk yaitu rasa gatal, bercak merah bekas gigitan nyamuk, bisa menyebabkan alergi bahkan di kasus lain yang lebih parah bisa terkena demam berdarah.

Berbagai upaya pengendalian baik secara kimia maupun alamiah telah dilakukan di beberapa wilayah. Berbagai larvasida dan insektisida telah digunakan untuk membunuh larva dan nyamuk dewasa, namun bahan aktif / senyawa kimia sintetik yang digunakan sebagai insektisida akan menyebabkan sifat resisten pada nyamuk karena seringnya paparan atau salah penggunaan dalam aplikasinya (Astuti, 2009)

Hingga saat ini pengendalian nyamuk belum bisa di tanggulangi dengan optimal. Di samping penyebarannya yang sangat luas dari wilayah perkotaan hingga ke pelosok pedesaan, nyamuk tersebut juga sangat mudah berkembang biak terutama di lingkungan sekitar tempat manusia beraktivitas. Tempat perindukan nyamuk sangat bervariasi, tetapi umumnya lebih menyukai berbagai macam tempat penampungan air jernih yang banyak terdapat di sekitar pemukiman penduduk, seperti bak mandi, tempayan dan barangbarang bekas yang menampung sisa-sisa hujan(Jacob et al., 2014). Sinar matahari merupakan faktor lingkungan fisik yang mempengaruhi keberadaan nyamuk dan berpengaruh pada kelembapan dan suhu. Pada beberapa jenis nyamuk suka berlindung di bawah lumut agar tidak terkena sinar matahari(Pratama, 2015)

Pengendalian Vektor DBD yang paling efisien dan efektif adalah dengan memutus rantai penularan melalui pemberantasan jentik. Pelaksanaannya di masyarakat dilakukan melaluiupaya Pemberantasan Sarang Nyamuk (PSN) dalam bentuk kegiatan $3 \mathrm{M}$ plus, yaitu : menguras dan menyikat tempat penampungan air (TPA), seperti bak mandi/wc seminggu sekali (M1), menutup rapat TPA, seperti gentong air, tempayan (M2), memanfaatkan atau mendaur ulang barang bekas yang dapat menampung air hujan (M3), selain itu ditambah (plus) dengan cara lainnya, seperti mengganti air vas bunga atau tempat lainnya yang sejenis seminggu sekali, memperbaiki saluran dan talang air yang tidak lancar/rusak, menaburkan bubuk larvasida/abate untuk membunuh jentik nyamuk, memelihara ikan pemakan jentik, memasang kawat kasa, menghindari kebiasaan menggantung pakaian dalam 
kamar, mengupayakan pencahayaan dan ventilasi ruang yang memadai, menggunakan kelambu, memakai obat yang dapat mencegah gigitan nyamuk. Untuk mendapatkan hasil yang diharapkan, kegiatan 3 M Plus ini harus dilakukan secara luas/serempak dan terus menerus /berkesinambungan. Apabila PSN dilaksanakan seluruh masyarakat maka diharapkan nyamuk Aedes aegypti yang merupakan vektor DBD dapat terbasmi. Untuk itu diperlukan usaha penyuluhan dan motivasi kepada masyarakat secara terus menerus dalam jangka waktu lama, karena keberadaan jentik nyamuk tersebut berkaitan erat dengan perilaku/ tindakan masyarakat(Azlina \& Anas, 2014).

Dari hal tersebut dirasa perlu melakukan penelitian untuk membuat perangkap nyamuk yang dapat mengurangi keberadaan nyamuk juga ramah lingkungan dan mudah dibuat.

\section{SOLUSI/TEKNOLOGI}

Dalam proyek yang dibuat kali ini, alat yang digunakan adalah perangkap nyamuk sederhana yang memanfaatkan genangan air dari kolam ikan dan jaring dari kain jala. Tempat sasaran adalah kebun FMIPA UNY terutama wilayah kolam. Sedangkan target sasaran adalah jentik-jentik atau benih nyamuk yang ditinggalkan oleh induknya.

Sasaran dari perangkap yang dibuat yakni bukan indukan nyamuk melainkan jentik-jentik karena alat yang dibuat akan memanfaatkan peranan rantai makanan dengan cara menjebak nyamuk untuk meletakkan benihnya di air kolam (sumber genangan air) namun kemudian benih tersebut dapat dimakan oleh ikan yang1. terdapat pada kolam. Sehingga dengan memodifikasi alat tersebut, nyamuk akan berkurang karena benihnya lenyap dimakan ikan, sedangkan ikan dapat memperoleh umpan dari alam.

Tahap persiapan awal yakni pembuatan perangkap (trap) untuk uji coba. Alat yang digunakan sebagai yakni ember plastik hitam berisi air hingga mencapai jaring yang digunakan untuk menutupi bagian atas ember. Jaring yang digunakan yakni yang lubangnya tidak terlalu besar namun cukup untuk seukuran benih nyamuk. Alat ini kemudian dipasang di area semak dan tempat yang banyak tertutupi tanaman di wilayah kebun FMIPA. Air yang diisikan ke dalam ember merupakan air murni atau tidak tercampur bahan apa pun dengan maksud mengilustrasikan ketika nantinya alat itu dipasang di kolam ikan yang memiliki $\mathrm{pH}$ netral dan tidak terkontaminasi bahan kimia buatan. Kemudian ember yang digunakan berwarna gelap dengan ilustrasi warna kolam dan untuk menarik perhatian nyamuk yang cenderung menyukai tempat gelap untuk hinggap. Mekanisme alat tersebut, yaitu nyamuk dewasa akan meletakkan telurnya di permukaan air. Telur yang diletakkan akan menetas setelah 1-2 hari dan menghasilkan larva nyamuk yang berenang bebas di air (di dalam ember di bawah paranet) hingga sampai pada tahap pupa dan menjadi nyamuk dewasa. Nyamuk dewasa tidak akan bisa keluar dari ember karena bagian atas ember tertutup oleh paranet. Uji coba alat dilakukan selama 17 hari

Setelah alat dibuat dan dipasang, dilakukan pengamatan setiap setidaknya 2 atau 3 hari sekali untuk memastikan alat tersebut bekerja. Proses pembuatan hingga pengujian alat berlangsung selama kurang lebih 2 minggu sebelum akhirnya alat akan dipasang di kolam sesungguhnya dan berperan sebagai perangkap jentik-jentik nyamuk.

\section{HASIL DAN DISKUSI}

1. Tabel Komponen Abiotik

\begin{tabular}{|c|c|c|}
\hline Penyusun & Parameter & Ukuran \\
\hline \multirow{2}{*}{$\begin{array}{c}\text { Iklim } \\
\text { Faktor }\end{array}$} & Suhu & $\mathbf{2 8}$ \\
\cline { 2 - 3 } & Kelembaban udara $\left({ }^{\circ} \mathbf{C}\right)$ & $\mathbf{6 5}$ \\
\cline { 2 - 3 } & Intensitas Cahaya $($ lux $)$ & $\mathbf{0}$ \\
\cline { 2 - 3 } & Kecepatan angin $(\mathbf{m} / \mathbf{d r})$ & $\mathbf{0}$ \\
\hline \multirow{2}{*}{$\begin{array}{c}\text { Tanah } \\
\text { Faktor }\end{array}$} & Kelembaban Tanah $(\boldsymbol{\%})$ & $\mathbf{2 0} \%$ \\
\cline { 2 - 3 } Edafik) & $\mathbf{p H}$ tanah & $\mathbf{7}$ \\
\cline { 2 - 3 } & $\mathbf{p H}$ air kolam & $\mathbf{6}$ \\
\cline { 2 - 3 } & Suhu Air kolam $\left({ }^{\circ} \mathbf{C}\right)$ & $\mathbf{2 5}$ \\
\hline
\end{tabular}


2. Tabel komponen Biotik

\begin{tabular}{|c|l|c|}
\hline Penyusun & \multicolumn{1}{|c|}{$\begin{array}{c}\text { Jenis-jenis } \\
\text { yang } \\
\text { ditemukan }\end{array}$} & Jumlah \\
\hline \multirow{4}{*}{ Produsen } & 1. Tegakan & $>50$ \\
\cline { 2 - 3 } & 2. Semak & $>70$ \\
\cline { 2 - 3 } & 3. Herba & $>100$ \\
\hline Konsumen & 1. Nyamuk & $>100$ \\
\cline { 2 - 3 } & 2. Katak & $>20$ \\
\cline { 2 - 3 } & 3. Ikan & $>20$ \\
\cline { 2 - 3 } 4. Kupu-kupu & $>20$ \\
\hline $\begin{array}{c}\text { Detritus dan } \\
\text { Dekomposer } \\
\text { yang } \\
\text { Teramati }\end{array}$ & 1. Jamur & $>10$ \\
\hline
\end{tabular}

3. Tabel Komponen Sosial Budaya

\begin{tabular}{|c|c|l|}
\hline $\begin{array}{c}\text { Jenis } \\
\text { Aktivitas }\end{array}$ & $\begin{array}{c}\text { Intensitas } \\
\text { (Sering/ } \\
\text { Jarang) }\end{array}$ & $\begin{array}{c}\text { Kondisi yang } \\
\text { Dipengaruhi }\end{array}$ \\
\hline $\begin{array}{c}\text { 1. Praktikum } \\
\text { Lapangan }\end{array}$ & Sering & $\begin{array}{l}\text { Kondisi ramai di } \\
\text { kebun biologi }\end{array}$ \\
\hline 2. Penelitian & Sering & $\begin{array}{l}\text { Banyak alat } \\
\text { penelitian }\end{array}$ \\
\hline
\end{tabular}

Berdasarkan penelitian yang telah dilakukan, banyaknya tegakan yang ada di Kebun Biologi FMIPA UNY menyebabkan sinar matahari tidak dapat menembus kanopi, sehingga intensitas cahaya yang diukur menunjukkan angka 0 dan tingkat kelembaban udara sebesar $65 \%$. Hal ini mendukung siklus hidup nyamuk, dimana nyamuk menyukai tempat gelap dan rindang dengan kelembaban tinggi, serta terdapat banyak kolam dengan $\mathrm{pH}$ dan suhu yang sesuai untuk pertumbuhan larva nyamuk. Jumlah nyamuk jauh lebih banyak jika dibandingkan dengan jumlah katak (predator nyamuk di alam), begitu pula jumlah ikan (predator telur dan larva nyamuk di alam) yang ada di setiap kolam lebih sedikit jika dibandingkan dengan jumlah telur dan larva nyamuk. Kelimpahan nyamuk ini menyebabkan aktivitas manusia menjadi terganggu karena gigitan nyamuk.

Kondisi sosial budaya di Laboratorium Kebun Biologi cukup ramai di hari-hari tertentu, karena digunakan sebagai tempat pembelajaran di lapangan sebelum terjun langsung di lapangan asli, juga digunakan sebagai tempat penelitian untuk mengambil data. Selain itu, tempat ini juga digunakan sebagai pusat pembelajaran dan pengolahan kompos dari sampah organik, hal ini juga mendukung adanya keberadaan nyamuk di tempat ini.

Siklus hidup nyamuk berawal dari peletakan telur oleh nyamuk betina. Dari telur muncul fase kehidupan air yang masih belum matang disebut larva dan akan berkembang menjadi empat tahap, kemudian bertambah ukuran hingga mencapai tahap akhir yang tidak membutuhkan asupan makanan yang disebut dengan pupa. Setelah terbentuk pupa, akan muncul nyamuk dewasa yang akan melakukan siklus hidup berikutnya.

Dalam daur hidup nyamuk dikenal dua alam atau lingkungan kehidupan yaitu air dan di luar air (darat atau udara). Stadium pra dewasa (telur, larva dan pupa) hidup di lingkungan air sedangkan stadium dewasa (nyamuk) hidup di luar air. Tempat perindukan nyamuk biasanya berupa genangan air yang tertampung disuatu tempat atau bejana(Wurisastuti, 2012).

Nyamuk meletakkan telur di atas permukaan air yang dapat mengapung karena di letakkan secara bergerombol dan bersatu membentuk rakit. Seekor nyamuk mampu meletakkan 100-400 butir telur.

Larva nyamuk memiliki sifon dengan beberapa kumpulan rambut yang membentuk sudut pada permukaan air. Larva memiliki 4 tingkatan, yaitu:

1. Larva Instar I

Larva Instar I, berukuran paling kecil 1 $2 \mathrm{~mm}$ atau $1-2$ hari setelah menetas. Duri-duri pada dada betina belum jelas dan corong pernafasan pada sifon belum jelas.

2. Larva Instar II

Larva Instar II, berukuran 2,5 - 3,4 mm atau $2-3$ hari setelah telur menetas. Duri - duri belum jelas, corong kepala mulai menghitam.

3. Larva Instar III

Larva Instar III, berukuran $4-5 \mathrm{~mm}$ atau $3-4$ hari setelah telur menetas. Duri-duri 
dada mulai jelas dan corong pernafasan berwarna coklat kehitaman.

4. Larva Instar IV

Larva Instar IV, berukuran paling besar yaitu $5-6 \mathrm{~mm}$ atau $4-6$ hari setelah telur menetas.

Pupa merupakan stadium akhir nyamuk di dalam air. Pada stadium ini pupa tidak membutuhkan makan. Pupa membutuhkan 2 - 5 hari. Sebagian kecil pupa kontak dengan permukaan air, berbentuk trompet, panjang dan ramping, setelah 1 - 2 hari akan menjadi nyamuk.

Berdasarkan keadaan yang ada di Kebun Biologi tersebut, maka dibuat sebuah alat penangkap telur nyamuk sederhana yang terbuat dari ember berisi air dan ditutup dengan paranet berwarna gelap hingga menyentuh permukaan air dalam ember. Mekanisme alat tersebut, yaitu nyamuk dewasa akan meletakkan telurnya di permukaan air. Telur yang diletakkan akan menetas setelah 1-2 hari dan menghasilkan larva nyamuk yang berenang bebas di air (di dalam ember di bawah paranet) hingga sampai pada tahap pupa dan menjadi nyamuk dewasa. Nyamuk dewasa tidak akan bisa keluar dari ember karena bagian atas ember tertutup oleh paranet.

4. Tabel Keadaan Dalam Trap

\begin{tabular}{|c|c|c|c|c|c|c|c|c|c|}
\hline \multirow{2}{*}{$\begin{array}{l}\text { Keadaan } \\
\text { di dalam } \\
\text { trap }\end{array}$} & \multicolumn{9}{|c|}{ Hari ke- } \\
\hline & 2 & 4 & 6 & 8 & 10 & 12 & 14 & 16 & 17 \\
\hline $\begin{array}{l}\text { Jumlah } \\
\text { rata-rata } \\
\text { telur } \\
\text { nyamuk }\end{array}$ & - & - & - & - & - & - & - & - & - \\
\hline $\begin{array}{c}\text { Jumlah } \\
\text { rata-rata } \\
\text { larva } \\
\text { nyamuk }\end{array}$ & $\begin{array}{c}> \\
57\end{array}$ & $\begin{array}{c}> \\
70\end{array}$ & $\begin{array}{c}> \\
70\end{array}$ & $\begin{array}{c}> \\
70\end{array}$ & $\begin{array}{c}> \\
70\end{array}$ & $\begin{array}{c}> \\
70\end{array}$ & $\begin{array}{c}> \\
70\end{array}$ & $\begin{array}{c}> \\
70\end{array}$ & $\begin{array}{c}> \\
70\end{array}$ \\
\hline $\begin{array}{c}\text { Jumlah } \\
\text { rata-rata } \\
\text { nyamuk }\end{array}$ & - & - & - & - & $\begin{array}{c}> \\
70\end{array}$ & $\begin{array}{c}> \\
70\end{array}$ & $\begin{array}{c}> \\
70\end{array}$ & $\begin{array}{c}> \\
70\end{array}$ & $\begin{array}{c}> \\
70\end{array}$ \\
\hline
\end{tabular}

Keterangan : $\quad(+)$ Teramati

( - ) Tidak Teramati

Uji coba alat dilakukan selama 17 hari dengan meletakkan tiga buah alat trap nyamuk di tiga lokasi berbeda di Kebun Biologi FMIPA
UNY. Berdasarkan tabel di atas, jumlah rata-rata nyamuk yang terperangkap di masing-masing alat sebanyak $>70$ ekor. Jika dari ketiga alat nyamuk yang tertangkap sebanyak $>140$. Hal ini menunjukkan angka penurunan jumlah nyamuk di Kebun Biologi yang relatif tinggi, dibuktikan dengan banyaknya jumlah nyamuk yang terperangkap di dalam alat tersebut. Namun, karena Kebun Biologi memiliki area yang luas dan tidak di setiap tempat dipasangi alat ini, maka hasil yang didapat pun tidak terlalu signifikan. Penelitian ini pun perlu dilakukan dalam waktu yang lama.

Untuk pengembangan dengan skala yang besar dapat menggunakan kolam yang berisi ikan lalu pada bagian pagar atau penutup digunakan paranet. Prinsipnya, jika nyamuk dewasa bertelur maka telurnya akan menempel pada paranet, setelah menetas, larvanya akan jatuh pada kolam ikan, dan disana larva akan dimakan oleh ikan. Hal ini juga sebagai alternatif sumber makanan untuk ikan, sehingga akan mengurangi pengeluaran untuk pembelian pakan ikan.

\section{KESIMPULAN}

Dari hasil penelitian dapat disimpulkan pembuatan Mosquito Trap dapat digunakan untuk mengurangi keberadaan nyamuk di Laboratorium Kebun Biologi FMIPA UNY, dibuktikan dengan banyaknya nyamuk yang terperangkap pada alat. Diharapkan dengan banyaknya nyamuk yang terperangkap dapat mengurangi gangguan nyamuk pada saat mahasiswa melakukan pembelajaran di Laboratorium Kebun Biologi FMIPA UNY.

\section{UCAPAN TERIMA KASIH}

Ucapan terima kasih diberikan kepada Dosen Ilmu Lingkungan I Gusti Putu Suryadarma, MS yang sudah mengarahkan dan membimbing kami hingga berlangsungnya penelitian ini, dan juga Bapak Suhandoyo, Ir., MS. yang telah memberikan informasi berkaitan tentang Laboratorium Kebun Biologi FMIPA UNY. 


\section{PUSTAKA}

Astuti, E. P. (2009). Efektifitas Alat Perangkap ( Trapping ) Nyamuk Vektor Demam Berdarah Dengue dengan Fermentasi Gula Effectiveness of Mosquito Trap with Sugar Fermented Attractant to the Vector of Dengue Hemorrhagic Fever. 41-48.

Azlina, A., \& Anas, E. (2014). Hubungan Tindakan Pemberantasan Sarang Nyamuk dengan Keberadaan Larva Vektor DBD di Kelurahan Lubuk Buaya. 5(1), 221-227.

Gama, Z. P., Yanuwiadi, B., \& Kurniati, T. H. (2010). Strategi Pemberantasan Nyamuk Aman Lingkungan : Potensi Bacillus thuringiensis Isolat Madura Sebagai Musuh Alami Nyamuk Aedes aegypti Safe Strategy to Control Mosquito: The Potential of Bacillus thuringiensis Isolate Indogenous from Madura as a Natural E. 1(1), 1-10.

Jacob, A., Pijoh, V. D., Skripsi, K., Kedokteran, F., Sam, U., \& Manado, R. (2014). Ketahanan hidup dan pertumbuhan nyamuk. 2(November).

Kadarohman, A. (2010). EFEKTIVITAS BIOLARVASIDA EKSTRAK ETANOL LIMBAH PENYULINGAN MINYAK AKAR WANGI ( Vetiveria zizanoides ) TERHADAP LARVA NYAMUK
Aedes aegypti , Culex sp ., dan Anopheles sundaicus. 1(1), 59-65.

Khoiriyah. (2016). EFEKTIVITAS ALAT PERANGKAP （TRAPPING ) NYAMUK VEKTOR DEMAM BERDARAH DENGUE DENGAN SKRIPSI Diajukan sebagai Salah Satu Syarat Untuk Memperoleh Gelar Sarjana Kesehatan Masyarakat Oleh Khoiriyah.

Nadifah, F., Farida Muhajir, N., Arisandi, D., \& D. Owa Lobo, M. (2017). Identifikasi Larva Nyamuk Pada Tempat Penampungan Air Di Padukuhan Dero Condong Catur Kabupaten Sleman. Jurnal Kesehatan Masyarakat Andalas, 10(2), 172. https://doi.org/10.24893/jkma.10.2.1 72-178.2016

Pratama, G. Y. (2015). NYAMUK Anopheles sp DAN FAKTOR YANG MEMPENGARUHI DI KECAMATAN RAJABASA, LAMPUNG SELATAN. 4(2013), 20-27.

Srisasi. (2000). No Title. 8-26.

Wurisastuti, T. (2012). Perilaku Bertelur Nyamuk Aedes aegypti pada Media Air Tercemar. (November 2012), 25-32.

Sunaryo, 2001. Pengaruh lingkungan terhadap nyamuk Anopheles pada Proses Transmis 